The Journal of Animal \& Plant Sciences, 31(4): 2021, Page: 1078-1086

ISSN (print): 1018-7081; ISSN (online): 2309-8694

\title{
IRRIGATION SCHEDULES AND PLANTING MODES IMPACT ON FARMLAND MICROCLIMATE AND DRY MATTER ACCUMULATION OF WINTER WHEAT
}

\author{
X. B. Zhou, Y. X. Hu, G. Y. Wang, and H. Y. Wu* \\ Guangxi Key Laboratory of Agric-Environment and Agric-Products Safety, Agricultural College of Guangxi University, \\ Nanning 530004, China. \\ *Corresponding author's e-mail: whyzxb@gmail.com
}

\begin{abstract}
The economic yield of wheat (Triticum aestivum $\mathrm{L}$ ) comes from the grain, and the dry matter accumulation of the grain is affected by the environmental factors, especially the temperature. A field experiment was conducted in Huanghuaihai Plain from 2014 to 2016 using the split-plot design with three replications following three irrigation schedules (main plot): irrigation of $50 \mathrm{~mm}$ each at jointing growth stage (GS34) and heading growth stage (GS48, W1); irrigation of $100 \mathrm{~mm}$ at GS48 (W2); and irrigation of $100 \mathrm{~mm}$ each at both GS34 and GS48 (W3) and three planting modes (split plot): uniform row $(\mathrm{U})$, furrow $(\mathrm{F})$, double-double row (DD) to explore the mechanism for improving yield and dry matter accumulation under reasonable temperature and relative humidity in farmland caused by irrigation and planting modes. The results showed that air temperature and relative humidity $(\mathrm{RH})$ at $5 \mathrm{~cm}$ aboveground $\left(\mathrm{AG}_{5}\right)$ were greater than those at $50 \mathrm{~cm}$ aboveground $\left(\mathrm{AG}_{50}\right)$ during the two growing seasons. The average air temperature at $\mathrm{AG}_{5}$ and $\mathrm{AG}_{50}$ of $\mathrm{W} 2$ was $3.69 \%$ higher than that of $\mathrm{W} 3$, and RH was $5.21 \%$ lower than that of W3. With the increasing irrigation amount (W3) and frequency (W1), the average air and soil temperature were reduced while RH, dry matter accumulation rate for stem, leaf, spike and yield were increased significantly. Although DD and F as good planting modes have been detected to improve $\mathrm{RH}$, dry matter and yield accumulation rates and decrease temperature as compared with $\mathrm{U}$, the DD contributed more towards them. The $\mathrm{AG}_{5}$ and $\mathrm{AG}_{50}$ average air temperatures had a significantly negative correlation with total dry matter and yield accumulation rate, whereas RH showed the opposite mode. Meanwhile, spike dry matter accumulation rate plays a dominant role in improving yield because there was an extreme significant positive correlation between spike and yield accumulation rate. Consequently, irrigation $50 \mathrm{~mm}$ each at GS34 and GS48 combined with double-double row planting mode is a good agronomy method to be applied in the regions of scarce water resources like the Huanghuaihai Plain based on the water-saving technology.
\end{abstract}

Keywords: air temperature; dry matter; relative humidity; soil temperature; Triticum aestivum L

\section{INTRODUCTION}

Wheat (Triticum aestivum L.), which constitutes the main source of the most important basic food stuffs of human beings (Lobell et al., 2013), is one of the most cultivated crops in the world, and irrigated regions contribute a large proportion to global wheat production (Asseng et al., 2017). Current population and economic growth mean a higher demand for food worldwide (Tilman et al., 2011). China is the greatest wheat producer in the world, and the Huanghuaihai Plain is a major wheat region in China. In this region, the precipitation is approximately $700 \mathrm{~mm}$, and approximately $25 \%-30 \%$ of the total precipitation occurs during the winter wheat growing season. The water source usually is a pressure for wheat growth because of the absence of underground and surface water (Shi and Shao, 2000), and a crucial limiting factor for wheat production is insufficient precipitation ( $\mathrm{Li}$ et al., 2009; Zhou et al., 2020). Therefore, irrigation is needed.

Climate change will positively or negatively affect crop yields. Previous studies have shown that wheat yield in some areas could be reduced by high temperatures
(Shimoda et al., 2015). The wheat yield is inversely related to temperature because high temperature accelerates crop phenological development, resulting in a shorter growing season with less grain yield (He et al., 2015), while it has a positive relationship with precipitation (Doğan and Kan, 2019).

Meteorological records show that mean annual temperatures over global areas where wheat is grown have increased by $\sim 1^{\circ} \mathrm{C}$ during the last century (Zhao et al., 2017). Crops are sensitive to changes in temperature and precipitation as a result of climate change (Rosenzweig et $a l ., 2014)$. European farmers are currently adapting to changing the timing of cultivation (Olsen et al., 2011). The adaptation of cropping systems to climate change provides less sensitive information on the climatic drivers of winter wheat production from time-series yield data (Licker et al., 2013). The use of plastic mulch and covered crops increased soil water storage and average soil temperature and decreased soil evaporation, which in turn increased wheat yield (He et al., 2017).

In our previous studies, an optimized planting mode combined with reasonable irrigation was a good 
agricultural practice to improve the farmland microclimate, including temperature and humidity (Wang et al., 2015). However, there is no comparison between the furrow and double planting modes under different irrigation schedules. To achieve this objective, we assessed irrigation schedules and planting modes based on air temperature, relative humidity $(\mathrm{RH})$, soil temperature and the dry matter and yield accumulation rate. The dry matter and grain yield of wheat are not only limited but increased as well provided optimum environmental factors during the growing season along with nutrients supported from the soil. A field experiment was conducted to test the hypothesis that farmland microclimates under different irrigation schedules and planting modes are crucial for high yield.

\section{MATERIALS AND METHODS}

Site description: The experiment was conducted at the Agronomy Experimental Station of Shandong Agricultural University, Tai'an, Shandong in China $\left(36^{\circ} 09^{\prime} \mathrm{N}\right.$, $117^{\circ} 09^{\prime} \mathrm{E}$ ) from October 2014 to June 2016. The mean monthly temperature and annual precipitation were $10.7^{\circ} \mathrm{C}$ and $245 \mathrm{~mm}(2014-2015), 10.8^{\circ} \mathrm{C}$ and $262 \mathrm{~mm}(2015-$ 2016), respectively (Fig. 1). The experimental field was a silt loam, and the $0-20 \mathrm{~cm}$ soil layer was characterized by a soil bulk density of $1.50 \mathrm{~g} \mathrm{~cm}^{-3}, \mathrm{pH}$ of 6.9 , soil organic matter content of $18.9 \mathrm{~g} \mathrm{~kg}^{-1}$, and available $\mathrm{N}, \mathrm{P}$, and $\mathrm{K}$ of $123.2 \mathrm{mg} \mathrm{kg} \mathrm{kg}^{-1}, 40.6 \mathrm{mg} \mathrm{kg}^{-1}$ and $124.5 \mathrm{mg} \mathrm{kg}{ }^{-1}$, respectively.

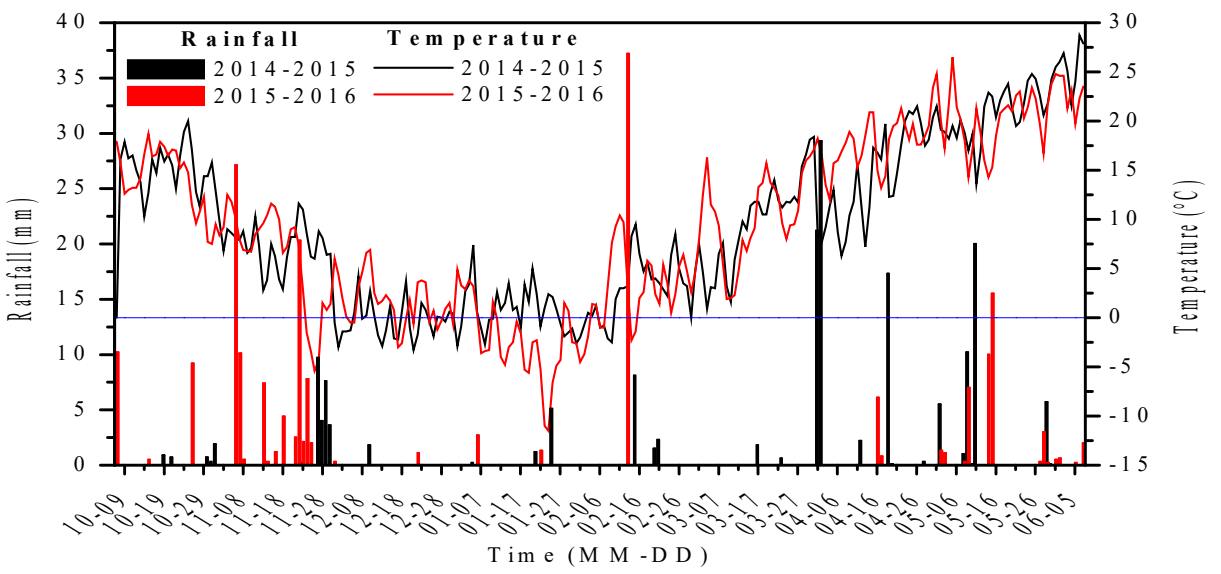

Fig. 1. Daily rainfall and air temperature during the 2014-2015 and 2015-2016 growth seasons.

Experimental design: Winter wheat and summer maize cropping system was adopted in the experiment site. After the harvest of summer maize on 27 Sept., 2014 and 30 Sept., 2015, the land prepared for seed bed was ploughed and levelled on 6 Oct., 2014 and 5 Oct., 2015. The winter wheat (cultivar Jimai 22) plant density was $200 \times 10^{4} \mathrm{ha}^{-1}$, and winter wheat was planted manually on 8 Oct., 2014 and 7 Oct., 2015 and harvested on 7 Jun., 2015 and 7 Jun., 2016 , respectively. The experimental plot area was $3 \times 3$ $\mathrm{m}^{2}$ with three replicates; $112.5 \mathrm{~kg} \mathrm{ha}^{-1} \mathrm{~N}, 120 \mathrm{~kg} \mathrm{ha}^{-1} \mathrm{P}_{2} \mathrm{O}_{5}$ and $105 \mathrm{~kg} \mathrm{ha}^{-1} \mathrm{~K}_{2} \mathrm{O}$ as base mineral fertilizers were added to the soil, and half of the total $\mathrm{N}\left(250.0 \mathrm{~kg} \mathrm{ha}^{-1}\right)$ was applied at the stem elongation stage (GS30, Zadoks et al., 1974) as a top-dressing. The experiment was conducted in a split-plot design. The main plot was the following three irrigation schedules: irrigation of $50 \mathrm{~mm}$ each at jointing growth stage (GS34, 27 Mar., 2015 and 27 Mar., 2016) and heading growth stage (GS48, 26 Apr., 2015 and 25 Apr., 2016) (W1); irrigation of $100 \mathrm{~mm}$ at GS48 (W2); and irrigation of $100 \mathrm{~mm}$ each at GS34 and GS48 (W3, Zadoks et al., 1974). Water was supplied to the plots using plastic pipes, and a flow meter was used to measure the irrigation amount. The plot was buried on all four sides using concrete slabs that were $2 \mathrm{~m}$ deep and $15 \mathrm{~cm}$ wide. The split plot consisted of the following three planting modes: uniform row (U), furrow (F), and double-double row (DD, Fig. 2). The row spacing was $30 \mathrm{~cm}$ for $U, 15 \mathrm{~cm}$ and $5 \mathrm{~cm}$ (double rows) alternated for DD, and $20 \mathrm{~cm}$ and $40 \mathrm{~cm}$ alternated for $\mathrm{F}$.

Farmland microclimate: The air temperature and $\mathrm{RH}$ were monitored at 5 and $50 \mathrm{~cm}$ aboveground $\left(\mathrm{AG}_{5}\right.$ and $\mathrm{AG}_{50}$ ), respectively, in the same inter-row space with a Pocket Weather Tracker Kestrel 4000 (Nielsen-Kellerman Co., Boothwyn, USA) at jointing (G35), flag leaf (GS44), heading (GS49), filling (GS71) and maturity (GS80) growth stages, respectively. The soil temperature at $0 \mathrm{~cm}$, $5 \mathrm{~cm}, 10 \mathrm{~cm}$, and $15 \mathrm{~cm}$ depth was measured in the center of the row from April 1 to May 30 every $6 \mathrm{~d}$ at 8:00 am and 14:00 pm with a geothermometer. The experiment was performed in triplicate.

Dry matter accumulation and yield: Dry matter was measured at GS80 following Zhou et al. (2021). The stochastically collected uniformly-growing fifteen strains and $1 \mathrm{~m}^{2}$ of wheat per plot as samples, in which the leaf, stem, and spike of fifteen strains of wheat per plot were separated, and dried in an oven at $105^{\circ} \mathrm{C}$ for $30 \mathrm{~min}$ followed by drying at $80^{\circ} \mathrm{C}$ until a constant weight was 
reached, and then dry matter and yield were determined. The dry matter accumulation rate was computed with the following equation: $\mathrm{ha}^{-1}$ )/days

Dry matter accumulation rate $=$ Dry matter $(\mathrm{kg}$

where days refers to the total number of days from sowing growth stage (GS0) to GS80 for stem, leaf and total dry matter, i.e., 234 days (2014-2015) and 238 days (2015-2016), respectively, and from GS49 to GS80 for grain, i.e., 38 days (2014-2015) and 43 days (20152016), respectively.

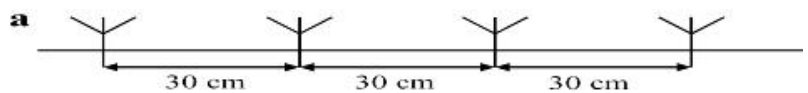

b

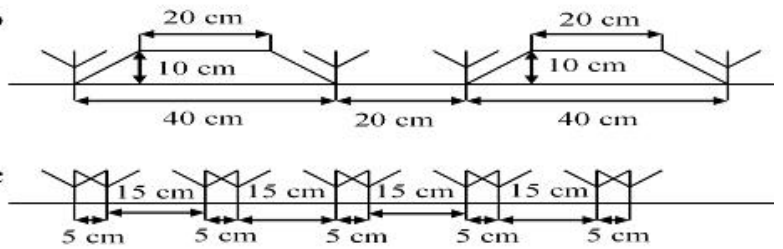

Fig. 2. Planting modes schematic diagram. a, uniform row (U); b, furrow (F); c, double-double row (DD).

Statistical analyses: All graphs were drawn with Origin 8 (OriginLab Corporation, Northampton, USA) and
SigmaPlot 12.5 (SPSS Inc., Chicago, USA), and all data were analyzed with SAS 9.2 software (SAS Institute Inc., Cary, NC, USA) using two-way ANOVA. The means of the different treatments were considered significant with the least significant difference (LSD) test at $P<0.05$.

\section{RESULTS}

Air temperature: The $\mathrm{AG}_{5}$ and $\mathrm{AG}_{50}$ temperatures were mainly influenced by air temperature and had an increasing trend during the growth stage (Fig. 3). There was a sharp decline at GS44 because of the low air temperature on $6 \mathrm{Apr} .\left(8.7^{\circ} \mathrm{C}\right), 7 \mathrm{Apr} .\left(6.3^{\circ} \mathrm{C}\right)$ and $8 \mathrm{Apr}$. $\left(7.7^{\circ} \mathrm{C}\right)$ during $2014-2015$. In 2014-2015, the $\mathrm{AG}_{5}$ and $\mathrm{AG}_{50}$ temperatures were $25.6^{\circ} \mathrm{C}$ and $25.3^{\circ} \mathrm{C}$; W1, W2 and W3 temperatures were $25.4^{\circ} \mathrm{C}, 25.7^{\circ} \mathrm{C}$ and $25.2^{\circ} \mathrm{C}$; and $\mathrm{F}$, $\mathrm{U}$ and DD temperatures were $25.2^{\circ} \mathrm{C}, 25.9^{\circ} \mathrm{C}$ and $25.2^{\circ} \mathrm{C}$, respectively (Fig. 3a1, a2). In 2015-2016, the $\mathrm{AG}_{5}$ and $\mathrm{AG}_{50}$ temperatures were $24.4^{\circ} \mathrm{C}$ and $23.7^{\circ} \mathrm{C}$; W1, W2 and W3 temperatures were $24.2^{\circ} \mathrm{C}, 24.6^{\circ} \mathrm{C}$ and $23.3^{\circ} \mathrm{C}$; and $\mathrm{F}$, $\mathrm{U}$ and DD temperatures were $23.8^{\circ} \mathrm{C}, 24.7^{\circ} \mathrm{C}$ and $23.6^{\circ} \mathrm{C}$, respectively (Fig. 3b1, b2). The air temperature at $\mathrm{AG}_{5}$ was greater than that at $\mathrm{AG}_{50}$ during the two growing seasons; the order of the average $\mathrm{AG}_{5}$ and $\mathrm{AG}_{50}$ temperatures was $\mathrm{W} 1 \approx \mathrm{W} 2>\mathrm{W} 3$ and $\mathrm{U}>\mathrm{F}>\mathrm{DD}$.

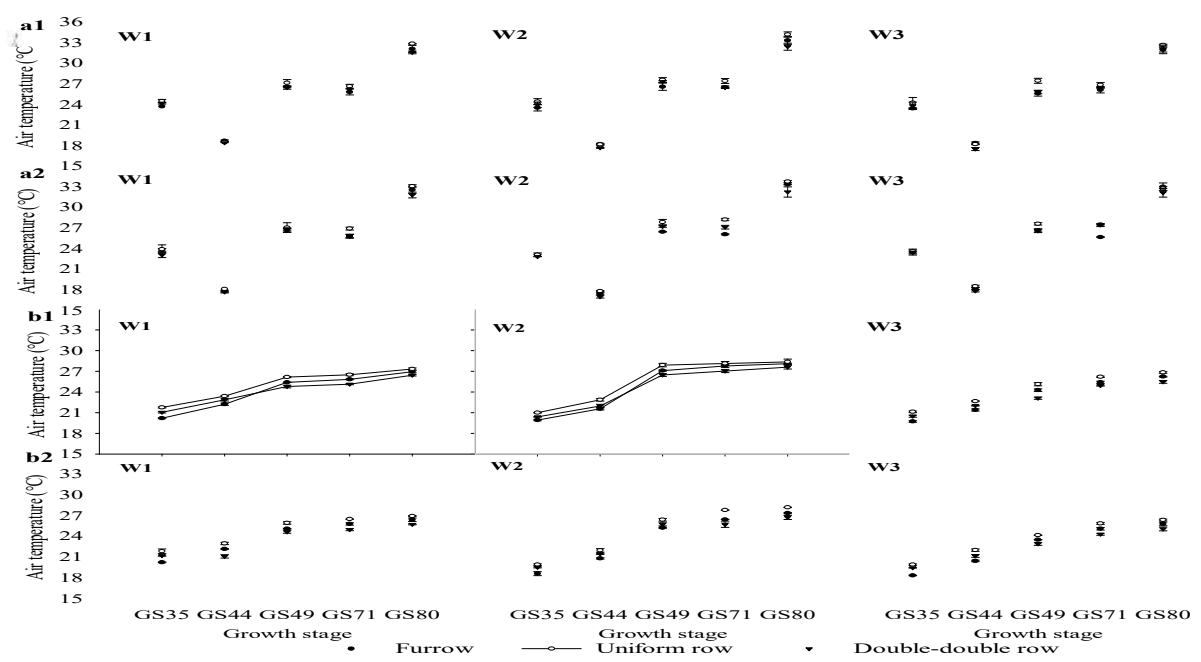

Fig. 3. Effects of planting modes and irrigation on air temperature. a1 and a2 represent air temperature at 5 and $50 \mathrm{~cm}$ aboveground in 2014-2015, b1 and b2 represent air temperature at 5 and $50 \mathrm{~cm}$ aboveground in 2015-2016; W1, irrigation of $50 \mathrm{~mm}$ each at GS34 and GS48; W2, irrigation of $100 \mathrm{~mm}$ at GS48; and W3, irrigation of $100 \mathrm{~mm}$ each at GS34 and GS48. The bars are the SE.

Relative humidity: The RH changes were similar to the temperatures at $\mathrm{AG}_{5}$ and $\mathrm{AG}_{50}$; there was an increase at GS44 because of rainfall on 16 Apr. (17.3 mm) during 2014-2015 and at GS35 and GS49 because of irrigation in 2015-2016. In 2014-2015, the RH at $\mathrm{AG}_{5}$ and $\mathrm{AG}_{50}$ was
$53.2 \%$ and $49.8 \%$, respectively; that of $\mathrm{W} 1, \mathrm{~W} 2$ and $\mathrm{W} 3$ was $51.0 \%, 50.8 \%$ and $52.7 \%$, respectively; and that of $\mathrm{F}$, $\mathrm{U}$ and DD was $51.9 \%, 49.7 \%$ and $52.9 \%$, respectively (Fig. 4a1, a2). 


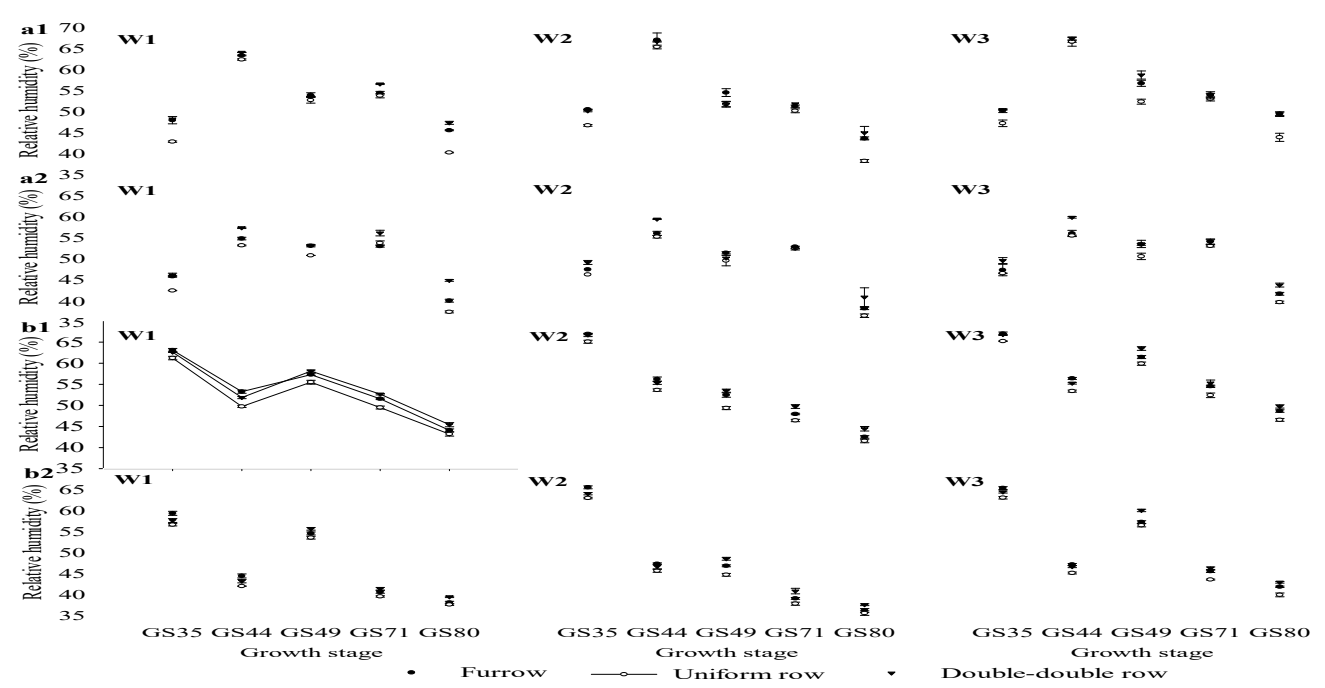

Fig. 4. Effects of planting modes and irrigation on relative humidity. a1 and a2 represent 5 and $50 \mathrm{~cm}$ aboveground in 2014-2015, b1 and b2 represent 5 and $50 \mathrm{~cm}$ aboveground in 2015-2016; W1, irrigation of $50 \mathrm{~mm}$ each at GS34 and GS48; W2, irrigation of $100 \mathrm{~mm}$ at GS48; and W3, irrigation of $100 \mathrm{~mm}$ each at GS34 and GS48. The bars are the SE.

In 2015-2016, the $\mathrm{RH}$ at $\mathrm{AG}_{5}$ and $\mathrm{AG}_{50}$ was $54.4 \%$ and $48.2 \%$, respectively; that of $\mathrm{W} 1, \mathrm{~W} 2$ and $\mathrm{W} 3$ was $50.1 \%, 49.7 \%$ and $54.0 \%$, respectively; and that of $\mathrm{F}$, $\mathrm{U}$ and DD was $51.7 \%, 49.9 \%$ and $52.2 \%$, respectively (Fig. 4b1, b2). During the two growing seasons, RH had a similar change, $\mathrm{AG}_{5}>\mathrm{AG}_{50}$; the average $\mathrm{RH}$ at $\mathrm{AG}_{5}$ and $\mathrm{AG}_{50}$ was ranked as $\mathrm{W} 3>\mathrm{W} 1 \approx \mathrm{W} 2$ and $\mathrm{DD}>\mathrm{F}>\mathrm{U}$.

Soil temperature: The soil temperature on 1 Apr., 7 Apr., 13 Apr., and 19 Apr. in 2016 was higher than that in 2015, but on 19 May, 25 May, and 30 May in 2016 was lower than that in 2015 (Fig. 5), which was similar to the air temperature change (Fig. 1). During the 2014-2016 growing seasons, the soil temperature at all levels presented a wave rising trend. The soil temperatures at 0 $\mathrm{cm}, 5 \mathrm{~cm}, 10 \mathrm{~cm}$ and $15 \mathrm{~cm}$ depths were $19.5^{\circ} \mathrm{C}, 16.2^{\circ} \mathrm{C}$, $15.6^{\circ} \mathrm{C}$ and $15.1^{\circ} \mathrm{C}$, respectively, indicating that the soil temperature decreased with the deepening of the soil layer. Soil temperatures at all levels were $\mathrm{W} 2>\mathrm{W} 1>\mathrm{W} 3$ and $\mathrm{U}$ $>$ DD $>$ F (Fig. 5). During the two growing seasons, the soil temperature averages at $0 \mathrm{~cm}, 5 \mathrm{~cm}, 10 \mathrm{~cm}$ and $15 \mathrm{~cm}$ depths were ranked as follows: $\mathrm{W} 2>\mathrm{W} 1>\mathrm{W} 3$ and $\mathrm{U}>$ $\mathrm{DD}>\mathrm{F}$.

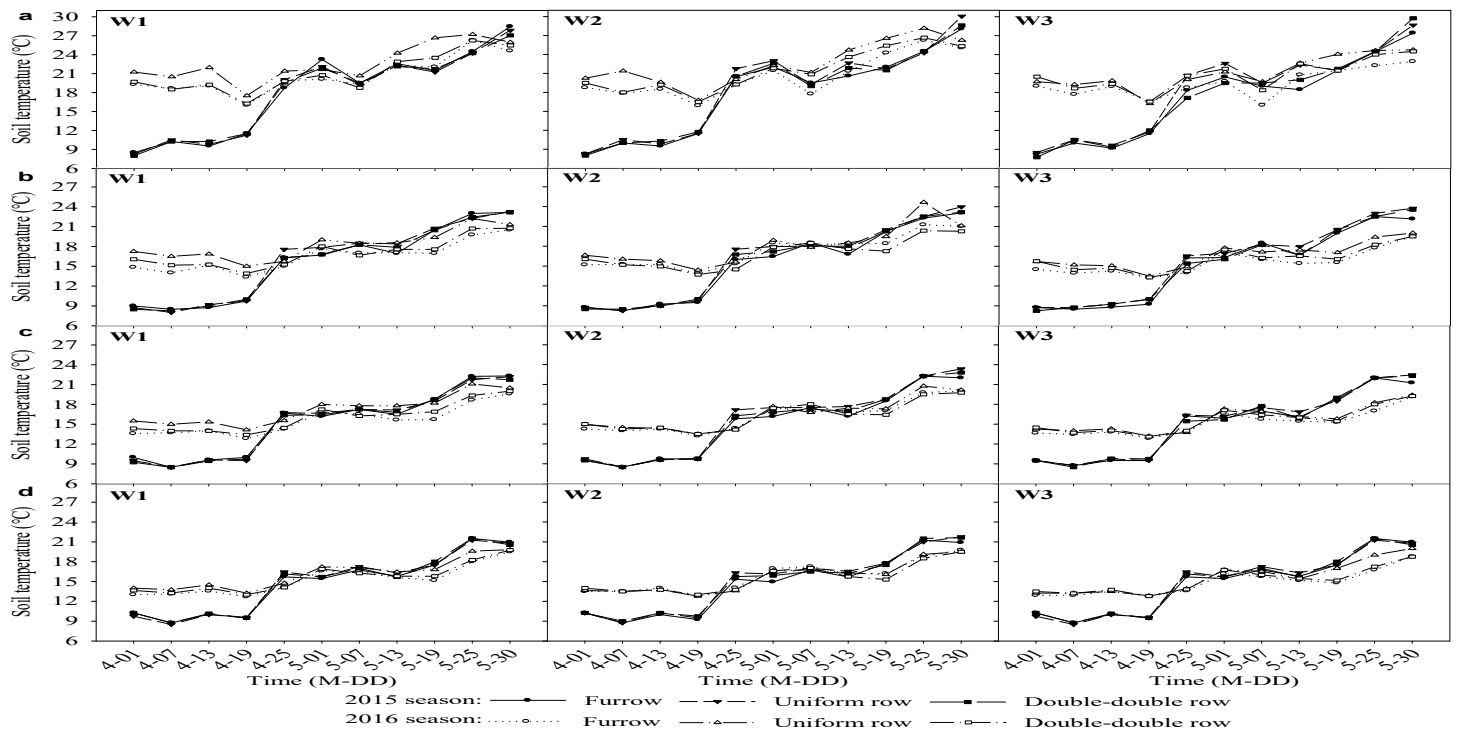

Fig. 5. Effects of planting modes and irrigation on soil temperature. a, b, c and d represent $0 \mathrm{~cm}, 5 \mathrm{~cm}, 10 \mathrm{~cm}$ and $15 \mathrm{~cm}$ depth; W1, irrigation of $50 \mathrm{~mm}$ each at GS34 and GS48; W2, irrigation of $100 \mathrm{~mm}$ at GS48; and W3, irrigation of $100 \mathrm{~mm}$ each at GS34 and GS48. 
Dry matter: The results showed that dry matter increased gradually with growth stage development (Fig. 6).

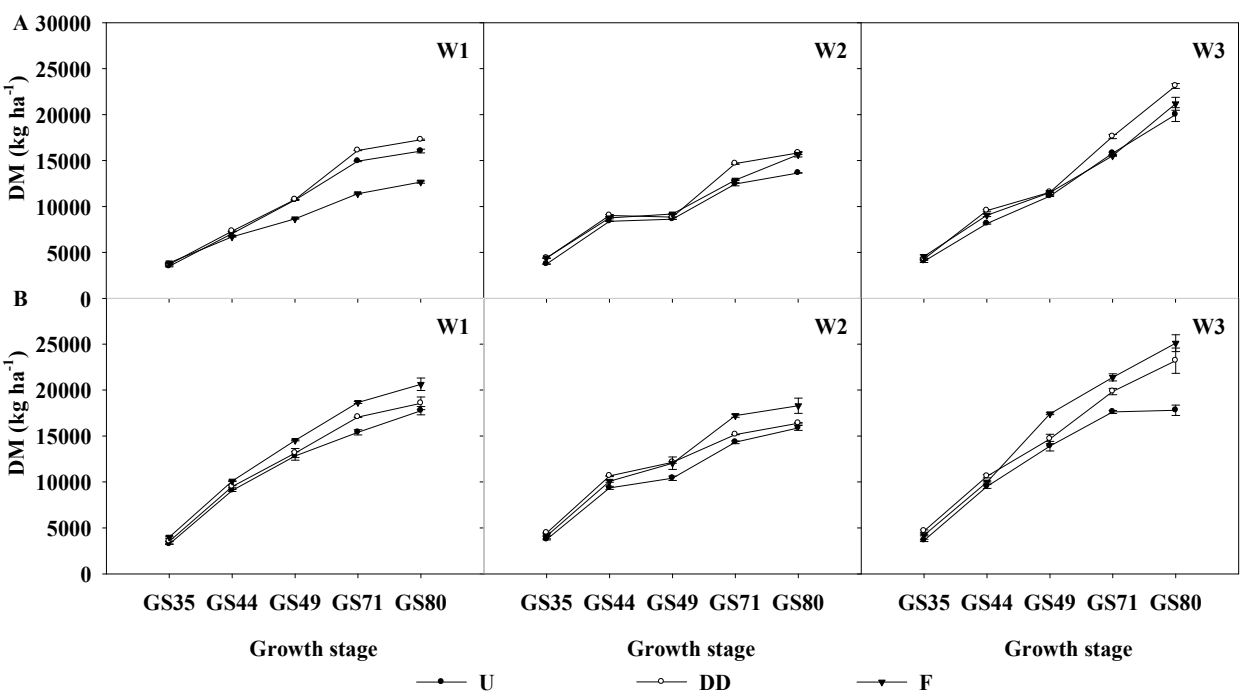

Fig. 6. The dry matter (DM) of winter wheat at different growth stages in 2014-2015 (A) and 2015-2016 (B). W1, irrigation of $50 \mathrm{~mm}$ each at GS34 and GS48; W2, irrigation of $100 \mathrm{~mm}$ at GS48; and W3, irrigation of 100 mm each at GS34 and GS48. U, uniform row; DD, double-double row; F, furrow; the bars were the SE.

In 2014-2015, the dry matter of W1, W2 and W3 were 10036, 10025 and $12462 \mathrm{~kg} \mathrm{ha}^{-1}$ respectively, W3 was significantly higher than those of $\mathrm{W} 1$ and $\mathrm{W} 2(P<$ 0.05); U, DD and F were 10537, 11595 and $10391 \mathrm{~kg} \mathrm{ha}^{-1}$ respectively, DD was significantly higher than those of $\mathrm{U}$ and $\mathrm{F}(P<0.01)$. At GS49-GS80, the dry matter of $\mathrm{U}$ and DD under W1 was higher than those of W2. In 2015-2016, the dry matter of W1, W2 and W3 were 12533, 11617 and $14240 \mathrm{~kg} \mathrm{ha}^{-1}$ respectively, W3 was significantly higher than that of $\mathrm{W} 2(P<0.05) ; \mathrm{U}, \mathrm{DD}$ and $\mathrm{F}$ were 11634 , 12907 and $13850 \mathrm{~kg} \mathrm{ha}^{-1}$ respectively. At GS71-GS80, the dry matter of $\mathrm{W} 1$ was higher than that of $\mathrm{W} 2$. The average dry matter of W3 was significantly higher than those of $\mathrm{W} 1$ and $\mathrm{W} 2$ by $18.31 \%$ and $23.38 \%(P<0.05)$; DD and $\mathrm{F}$ were significantly higher than those of $U$ by $10.51 \%$ and 9.34\% $(P<0.05)$.

Dry matter and yield accumulation rates: The spike dry matter accumulation rate was the highest, followed by that of the yield, stem and then the leaf during the growing season (Table 1).

Table 2. The correlation analysis between total dry matter and yield accumulation rate, air and soil temperatures, and relative humidity.

\begin{tabular}{|c|c|c|c|c|c|c|}
\hline Variable & $\begin{array}{c}\text { Air } \\
\text { temperature }\end{array}$ & $\begin{array}{c}\text { Soil } \\
\text { temperature }\end{array}$ & $\begin{array}{l}\text { Relative } \\
\text { humidity }\end{array}$ & $\begin{array}{c}\text { Spike } \\
\text { accumulation rate }\end{array}$ & $\begin{array}{l}\text { Total dry } \\
\text { matter }\end{array}$ & $\begin{array}{c}\text { Yield } \\
\text { accumulation } \\
\text { rate }\end{array}$ \\
\hline Air temperature & 1.0000 & -0.3599 & $-0.5494^{*}$ & $-0.5219^{*}$ & $-0.6152^{* *}$ & $-0.5709^{*}$ \\
\hline Soil temperature & & 1.0000 & $-0.4652^{*}$ & -0.1741 & -0.1282 & -0.4511 \\
\hline Relative humidity & & & 1.0000 & $0.6162^{* *}$ & $0.6655^{* *}$ & $0.8962^{* *}$ \\
\hline $\begin{array}{l}\text { Spike accumulation } \\
\text { rate }\end{array}$ & & & & 1.0000 & $0.9877^{* *}$ & $0.7507^{* *}$ \\
\hline Total dry matter & & & & & 1.0000 & $0.7789^{* *}$ \\
\hline $\begin{array}{l}\text { Yield accumulation } \\
\text { rate }\end{array}$ & & & & & & 1.0000 \\
\hline
\end{tabular}

Average air temperature and relative humidity at 5 and $50 \mathrm{~cm}$ aboveground; average soil temperature at $0 \mathrm{~cm}, 5 \mathrm{~cm}, 10 \mathrm{~cm}$ and $15 \mathrm{~cm}$ depth in 2014-2015 and 2015-2016.

${ }^{*},{ }^{* *}$ Correlation is significant at the 0.05 and 0.01 levels, respectively.

The spike, total dry matter and yield accumulation rates in 2015-2016 were higher than those in 2014-2015 (except U and DD under W1, and U under
W3). No matter what planting mode was applied in winter wheat in both years, the dry matter and yield accumulation rate of W3 were significantly higher than those of $\mathrm{W} 1$ and 
W2 $(P<0.05)$. Additionally, $\mathrm{W} 1$ resulted in more pronounced increment in dry matter and yield accumulation rate related to W2. Dry matter accumulation rate was significantly affected not only by the irrigation, but also by the planting modes $(P<0.05)$. The dry matter accumulation rates at different organs of wheat in DD and $F$ remained higher than those in $U$ in both years. However, the dry matter accumulation rates in DD and F showed the opposite trend in two years as DD contributed more towards dry matter and yield than F in 2014-2015. Either irrigation or planting modes interacted with years significantly affected spike dry matter and yield accumulation rates $(P<0.05)$. Although not statistically significant $(P>0.05)$, the average dry matter of two years in DD was improved by $4.2 \%$ for spike and $3.3 \%$ for total dry matter compared in relation to $F$. The average accumulation rate in two years was $209.7 \mathrm{~kg} \mathrm{ha}^{-1} \mathrm{~d}^{-1}$ for $\mathrm{F}$ and $207.5 \mathrm{~kg} \mathrm{ha}^{-1} \mathrm{~d}^{-1}$ for DD, showing no significant difference between the yield accumulation rates of DD and $\mathrm{F}(P>0.05)$.

Correlation between air and soil temperatures, relative humidity, spike and total dry matter and yield accumulation rates: The $\mathrm{RH}$ had a significantly negative correlation with air temperature and soil temperature $(P<$ $0.05)$, with $r$ values of -0.5494 and -0.4652 , respectively (Table 2). A significant linear regression relationship. With an equation of $\mathrm{y}=82.7347-1.2668 \mathrm{x}\left(\mathrm{R}^{2}=0.5347\right.$, $P<0.0001)$ between $\mathrm{RH}$ with air temperature is shown in Fig. 7, showing that $\mathrm{RH}$ is decreased with the increasing of air temperature $(P<0.0001)$.

Table 1. Effects of planting modes and irrigation on the dry matter accumulation rate $\left(\mathrm{kg} \mathrm{ha}^{-1} \mathrm{~d}^{-1}\right)$.

\begin{tabular}{|c|c|c|c|c|c|c|c|c|c|c|c|}
\hline \multirow{2}{*}{ Irrigation } & \multirow{2}{*}{$\begin{array}{l}\text { Planting } \\
\text { mode } \\
(\mathrm{PM})\end{array}$} & \multicolumn{2}{|c|}{ Stem } & \multicolumn{2}{|c|}{ Leaf } & \multicolumn{2}{|c|}{ Spike } & \multicolumn{2}{|c|}{ Total } & \multicolumn{2}{|c|}{ Yield } \\
\hline & & 2015 & 2016 & 2015 & 2016 & 2015 & 2016 & 2015 & 2016 & 2015 & 2016 \\
\hline \multirow{4}{*}{ W1 } & Furrow & $17.8^{\mathrm{e}}$ & $20.8^{\mathrm{c}}$ & $5.6^{\mathrm{e}}$ & $7.2^{\mathrm{bc}}$ & $209.9^{f}$ & $324.5^{b}$ & $57.5^{\mathrm{g}}$ & $86.7^{\mathrm{c}}$ & $201.6^{\mathrm{d}}$ & $213.3^{c}$ \\
\hline & $\begin{array}{l}\text { Uniform } \\
\text { row }\end{array}$ & $24.3^{\mathrm{b}}$ & $18.9^{\text {cde }}$ & $5.7^{\mathrm{e}}$ & $5.9^{\mathrm{de}}$ & $301.0^{\mathrm{d}}$ & $\underset{\mathrm{d}}{275.4^{\mathrm{c}}}$ & $79.0^{\mathrm{d}}$ & $74.6^{\mathrm{de}}$ & $181.2^{\mathrm{f}}$ & $166.8^{\mathrm{g}}$ \\
\hline & $\begin{array}{l}\text { Double- } \\
\text { double } \\
\text { row }\end{array}$ & $24.7^{\mathrm{b}}$ & $19.7^{\mathrm{cd}}$ & $8.3^{\mathrm{a}}$ & $6.5^{\mathrm{cd}}$ & $310.0^{c}$ & $286.2^{c}$ & $83.4^{\mathrm{c}}$ & $78.0^{\mathrm{d}}$ & $\underset{\mathrm{b}}{213.4^{\mathrm{a}}}$ & $193.8^{\mathrm{d}}$ \\
\hline & Furrow & $21.0^{\mathrm{cd}}$ & $19.1^{\text {cde }}$ & $6.5^{\mathrm{d}}$ & $6.0^{\mathrm{de}}$ & $238.3^{\mathrm{e}}$ & $286.7^{c}$ & $66.3^{\mathrm{f}}$ & $76.9^{\mathrm{d}}$ & $190.2^{\mathrm{e}}$ & $\underset{\mathrm{e}}{189.6^{\mathrm{d}}}$ \\
\hline \multirow[t]{3}{*}{ W2 } & $\begin{array}{l}\text { Uniform } \\
\text { row }\end{array}$ & $19.1^{\mathrm{de}}$ & $17.4^{\mathrm{e}}$ & $4.9^{\mathrm{f}}$ & $5.2^{\mathrm{e}}$ & $236.0^{\mathrm{e}}$ & $244.2^{\mathrm{d}}$ & $62.4^{\mathrm{h}}$ & $66.7^{\mathrm{f}}$ & $183.1^{\mathrm{ef}}$ & $169.5^{\mathrm{fg}}$ \\
\hline & $\begin{array}{l}\text { Double- } \\
\text { double } \\
\text { row }\end{array}$ & $21.6^{\mathrm{c}}$ & $18.6^{\mathrm{de}}$ & $7.1^{\mathrm{c}}$ & $5.7^{\mathrm{de}}$ & $242.6^{\mathrm{e}}$ & $246.8^{\mathrm{d}}$ & $68.1^{\mathrm{e}}$ & $68.9^{\mathrm{ef}}$ & $199.6^{\mathrm{d}}$ & $178.9^{\mathrm{ef}}$ \\
\hline & Furrow & $27.9^{\mathrm{a}}$ & $26.6^{\mathrm{a}}$ & $7.8^{\mathrm{b}}$ & $9.7^{\mathrm{a}}$ & $300.9^{d}$ & $382.4^{\mathrm{a}}$ & $84.5^{\mathrm{c}}$ & $105.5^{\mathrm{a}}$ & $\underset{c}{210.7^{b}}$ & $252.9^{\mathrm{a}}$ \\
\hline \multirow[t]{2}{*}{ W3 } & $\begin{array}{l}\text { Uniform } \\
\text { row }\end{array}$ & $25.4^{\mathrm{b}}$ & $20.1^{\mathrm{cd}}$ & $7.1^{\mathrm{c}}$ & $6.3^{\mathrm{cd}}$ & $334.8^{\mathrm{b}}$ & $\begin{array}{c}267.9^{c} \\
\mathrm{~d}\end{array}$ & $87.0^{\mathrm{b}}$ & $74.8^{\mathrm{de}}$ & $\begin{array}{c}203.9^{c} \\
\mathrm{~d}\end{array}$ & $198.9^{\mathrm{d}}$ \\
\hline & $\begin{array}{c}\text { Double- } \\
\text { double } \\
\text { row }\end{array}$ & $29.4^{\mathrm{a}}$ & $23.5^{\mathrm{b}}$ & $8.6^{\mathrm{a}}$ & $7.8^{\mathrm{b}}$ & $363.6^{\mathrm{a}}$ & $366.2^{\mathrm{a}}$ & $97.1^{\mathrm{a}}$ & $97.5^{\mathrm{b}}$ & $219.9^{\mathrm{a}}$ & $239.5^{\mathrm{b}}$ \\
\hline \multicolumn{2}{|c|}{ Source of variance } & & & & & $P>F$ & & & & & \\
\hline \multicolumn{2}{|c|}{ Irrigation } & 0.0038 & $\begin{array}{c}0.000 \\
5\end{array}$ & $\begin{array}{c}0.000 \\
1\end{array}$ & $\begin{array}{c}0.001 \\
6\end{array}$ & $\begin{array}{c}0.000 \\
1\end{array}$ & 0.0001 & $\begin{array}{c}0.000 \\
1\end{array}$ & $\begin{array}{c}0.000 \\
1\end{array}$ & 0.0001 & 0.0006 \\
\hline \multicolumn{2}{|c|}{ PM } & 0.0001 & $\begin{array}{c}0.000 \\
3\end{array}$ & $\begin{array}{c}0.000 \\
1\end{array}$ & $\begin{array}{c}0.000 \\
2\end{array}$ & $\begin{array}{c}0.000 \\
1\end{array}$ & 0.0002 & $\begin{array}{c}0.000 \\
1\end{array}$ & $\begin{array}{c}0.000 \\
1\end{array}$ & 0.0001 & 0.0001 \\
\hline \multicolumn{2}{|c|}{ Irrigation $\times \mathrm{PM}$} & 0.0001 & $\begin{array}{c}0.035 \\
1\end{array}$ & $\begin{array}{c}0.000 \\
1\end{array}$ & $\begin{array}{c}0.027 \\
2\end{array}$ & $\begin{array}{c}0.000 \\
1\end{array}$ & 0.0252 & $\begin{array}{c}0.000 \\
1\end{array}$ & $\begin{array}{c}0.000 \\
1\end{array}$ & 0.0467 & 0.0006 \\
\hline \multicolumn{2}{|c|}{ Years $\times$ Irrigation } & \multicolumn{2}{|c|}{0.1788} & \multicolumn{2}{|c|}{0.0637} & \multicolumn{2}{|c|}{0.0018} & \multicolumn{2}{|c|}{0.0001} & \multicolumn{2}{|c|}{0.0003} \\
\hline \multirow{2}{*}{\multicolumn{2}{|c|}{$\begin{array}{c}\text { Years } \times \text { PM } \\
\text { Years } \times \text { Irrigation } \times\end{array}$}} & \multicolumn{2}{|c|}{0.0012} & \multicolumn{2}{|c|}{0.0008} & \multicolumn{2}{|c|}{0.0001} & \multicolumn{2}{|c|}{0.0001} & \multicolumn{2}{|c|}{0.0001} \\
\hline & & \multicolumn{2}{|c|}{0.0015} & \multicolumn{2}{|c|}{0.0004} & \multicolumn{2}{|c|}{0.0076} & \multicolumn{2}{|c|}{0.0001} & \multicolumn{2}{|c|}{0.0252} \\
\hline
\end{tabular}

W1, irrigation of $50 \mathrm{~mm}$ each at GS34 and GS48; W2, irrigation of $100 \mathrm{~mm}$ at GS48; and W3, irrigation of $100 \mathrm{~mm}$ each at GS34 and GS48. Values followed by different letters in the same column are significantly different according to $\operatorname{LSD}_{0.05}$. 


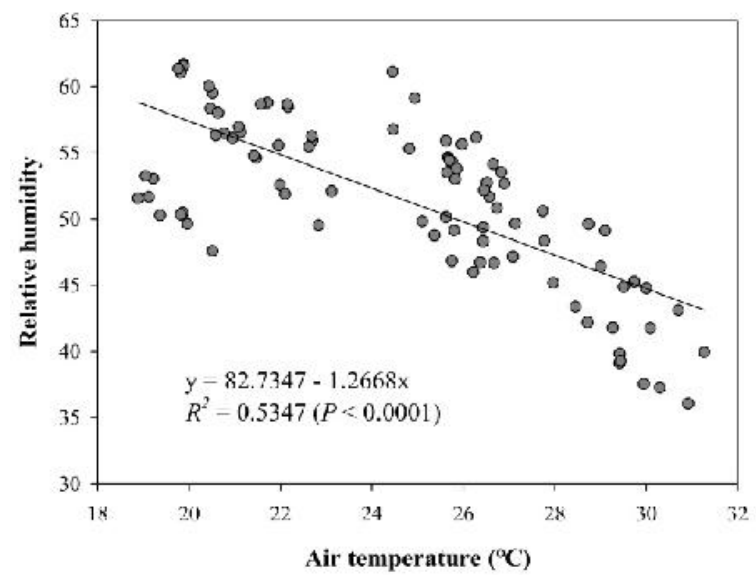

Fig. 7. Regression analysis of air temperature and relative humidity in the field of winter wheat.

The spike and total dry matter accumulation rates were significantly negatively correlated with air temperature while they had a significant positive correlation with $\mathrm{RH}$ and spike accumulation rate $(P<$ 0.01 ), with a $r$ value of 0.6162 and 0.6655 , respectively. A significant positive correlation with spike and total dry matter accumulation rate was found, and $r$ value was $0.9877(P<0.01)$. Moreover, yield accumulation rate had a negative correlation with air or soil temperature but it was significantly positively correlated with $\mathrm{RH}$, spike and total dry matter accumulation rates $(P<0.01)$. The results showed that relatively high RH could increase dry matter accumulation, which improved yield accumulation rate; however, high temperature was an unfavorable factor for wheat production.

\section{DISCUSSION}

The cultivation mode changed the ecological environment of wheat growth, which affected the physiological process of wheat and led to the change of yield (Izzi et al., 2008). Other agricultural practices, including tillage, fertilizer, sowing date, straw return, irrigation, and planting pattern, will influence the farmland microclimate. Different irrigation treatments have different microclimate characteristics, and irrigation significantly reduce formation of temperature and increase RH (Lu et al., 2015). The results of present study also showed that, with increasing of irrigation amount, the air temperature decreased and the $\mathrm{RH}$ increased at $\mathrm{AG}_{5}$ and $A_{50}$. The air temperature at $A_{5}$ and $A G_{50}$ had a significant negative correlation with yield and spike dry matter accumulation rate, whereas RH was reverse. Previous research has shown that temperature increase has the most likely negative impact on crop yields (Ottman et al., 2012) which was confirmed in our study. The DD (wide-precision) and $\mathrm{F}$ were good planting modes, which weaken competition among individual crop plants (Yan et al., 2018).

Irrigation could reduce soil temperature while increase $\mathrm{RH}$, and temperature change range decreased with increasing of soil depth. The W3 maintained the lowest air temperature and the highest RH. At the same time, the increase in the irrigation frequency by reducing the irrigation amount per application will relatively decrease temperature and improve RH. Feng et al. (2017) reported that increasing irrigation frequency would maintain higher soil water content in top soil layer, which might result in low temperature and high RH in W1 and then promote dry matter as well as yield accumulation rate. The regions with scarce water resources like north China, W1 was considered to be the optimal water-saving irrigation mode. Reasonable plant spacing could decrease heat consumption for evapotranspiration and improve the microclimate of farmland. This study showed that DD significantly reduced air temperature at $\mathrm{AG}_{5}$ and $\mathrm{AG}_{50}$, and improved air humidity. These were consistent with previous studies (Philip et al., 2005).

The dry matter mass was biological yield, and high biological yield was also an excellent character of wheat. The increment of dry matter partitioning to the spikes could increase grain partitioning leading to high yield as a significant positive correlation between spike with yield accumulation rates was found, which was identified with the report of Rivera-Amado et al. (2019). The experimental results showed that the total dry matter and yield accumulation rates of winter wheat increased with the increase of irrigation times under irrigation quota as well as irrigation amount, so the total dry matter and yield accumulation rate of $\mathrm{W} 3$ were higher than those of other irrigation treatments. The total dry matter of DD planting mode was relatively better than that of other planting modes. In conclusion, the total larger dry matter was beneficial to increase grain yield.

Irrigation schedules and planting modes improved farmland microclimate and contributed to increase dry matter accumulation (Plaut et al., 2004). Dry matter is the final form of photosynthetic products of crops, and its accumulation, transport and distribution are closely related to formation of economic yield (Guo et al., 2020). Studies have shown that most of wheat grain yield comes from the redistribution of post-flowering photosynthetic production and pre-flowering storage, and suitable irrigation can significantly increase dry matter accumulation after flowering and its contribution to grain yield, thus increasing the yield (Ma et al., 2019). Irrigation can promote the transfer of preanthesis homologous compounds to seeds, and narrow row planting can improve the yield of maize by improving its dry matter production capacity (Lin et al., 2016). In this study, dry matter accumulation for stem, leaf and spike increased with increasing of irrigation amount and frequency in DD were superior to other planting modes, which it may be due to 
the large population number in the DD, and created suitable field microclimate for the growth of winter wheat and the grain dry accumulation. Additionally, years interacted with planting mode and irrigation also significantly affected dry matter accumulation for stem, leaf, spike and grain $(P<0.05)$. Higher dry matter and yield accumulation were found in 2015-2016 rather than in 2014-2015, which might be attributed to the precipitation in 2015-2016 (262 $\mathrm{mm})$ being higher than that in 2014-2015 (245 mm).

As have discussed above, the results showed that irrigation amount and frequency could decrease air temperature and increase RH, dry matter and yield accumulation. Soil temperature decreases with increasing soil depth. Irrigation schedules and planting modes have important impacts on farmland microclimate, including air and soil temperatures and RH, and changes in the microclimate accelerate or retard crop growth, especially dry matter accumulation. DD is a new precision planting mode, compared with $\mathrm{F}$ and $\mathrm{U}$. The temperature and precipitation records help to analyze the microclimate. By improving irrigation schedules under field conditions, we confirmed the best planting mode to prevent agricultural water stress. This experiment showed that F and DD decreased air and soil temperatures and increased the RH and dry matter and yield accumulation rates compared with $U$, but the dry matter and yield accumulation rates of DD were relatively high. It may be recommended that farmers with scarce water resources (like this area) could adopt W1 with DD due to scarce water resources in the Huanghuaihai Plain.

Acknowledgements: The research was sponsored by the National Natural Science Foundation of China (31760354), the National High Technology Research and Development Program of China (2013AA102903). We wish to thank Zhang Zhen for help in collecting experimental data. We would like to thank American Journal Experts (https://www.aje.com) for editing and reviewing this manuscript for English language.

\section{REFERENCES}

Asseng, S., D. Cammarano, B. Basso, U. Chung, P.D. Alderman, K. Sonder, M. Reynolds, and D.B. Lobell (2017). Hot spots of wheat yield decline with rising temperatures. Global Change Biol. 23: $2464-2472$.

Doğan, H.G., and A. Kan (2019). The effect of precipitation and temperature on wheat yield in Turkey: a panel FMOLS and panel VECM approach. Environ. Dev. Sustain. 21: 447-460.

Feng, S., S. Gu, H. Zhang, and D. Wang (2017). Root vertical distribution is important to improve water use efficiency and grain yield of wheat. Field Crops Res. 214: 131-241.
Guo, X., Y. Hu, H. Jiang, Y. Lan, H. Wang, L. Xu, D. Yin, H. Wang, G. Zheng, Y. Lv (2020). Improving photosynthetic production in rice using integrated crop management in northeast china. Crop Sci. 60: 454-465.

He, G., Z. Wang, X. Ma, H. He, H. Cao, S. Wang, J. Dai, L. Luo, M. Huang, and S.S. Malhi (2017). Wheat yield affected by soil temperature and water under mulching in dryland. Agron. J. 109: 29983006.

He, L., S. Asseng, G. Zhao, D. Wu, X. Yang, W. Zhuang, N. Jin, and Q. Yu (2015). Impacts of recent climate warming, cultivar changes, and crop management on winter wheat phenology across the Loess Plateau of China. Agr. Forest Meteorol. 200: 135-143.

Izzi, G., H.J. Farahani, A. Bruggeman and T.Y. Oweis (2008). In-season wheat root growth and soil water extraction in the Mediterranean environment of northern Syria. Agric. Water Manage. 3: 259-270.

Li, S.X., Z.H. Wang, S.S. Malhi, S.Q. Li, Y.J. Gao, and X.H. Tian (2009). Nutrient and water management effects on crop production, and nutrient and water use efficiency in dryland areas of China. Adv. Agron. 102: 223-265.

Licker, R., C.J. Kucharik, T. Doré, M.J. Lindeman, and D. Makowski (2013). Climatic impacts on winter wheat yields in Picardy, France and Rostov, Russia: 1973-2010. Agr. Forest Meteorol. 176: 25-37.

Lin, P., H. Qi, C.F. Li, and M. Zhao (2016). Optimized tillage practices and row spacing to improve grain yield and matter transport efficiency in intensive spring maize. Field Crops Res. 198: 258-268.

Lobell, D.B., G.L. Hammer, G. McLean, C. Messina, M.J. Roberts, and W. Schlenker (2013). The critical role of extreme heat for maize production in the United States. Nat. Clim. Change. 3: 497-501.

Lu, G.H., J.Q. Song, W.B. Bai, Y.F. Wu, Y. Liu, and Y.H. Kang (2015). Effects of different irrigation methods on micro-environments and root distribution in winter wheat fields. J. Integr. Agr. 14: 1658-1672.

Ma, S.C., W.Q. Zhang, A.W. Duan, and T.C. Wang (2019). Effects of controlling soil moisture regime based on root-sourced signal characteristics on yield formation and water use efficiency of winter wheat. Agric. Water Manage. 221: 486-492.

Olsen, J.E., M. Trnka, K.C. Kersebaum, A.O. Skjelvåg, B. Seguin, P. Peltonen-Sainio, F. Rossi, J. Kozyra, and F. Micale (2011). Impacts and adaptation of European crop production systems to climate change. Eur. J. Agron. 34: 96-112. 
Ottman, M.J., B.A. Kimball, J.W. White, and G.W. Wall (2012). Wheat growth response to increased temperature from varied planting dates and supplemental infrared heating. Agron. J. 104: 716.

Philip, E., and P. Mustafa (2005). Crop row spacing and its influence on the partitioning of evapotranspiration by winter-grown wheat in Northern Syria. Plant Soil 268: 195-208

Plaut, Z., B.J. Butow, C.S. Blumenthal, and C.W. Wrigley (2004). Transport of dry matter into developing wheat kernels and its contribution to grain yield under post-anthesis water deficit and elevated temperature. Field Crops Res. 86: 185-198.

Rivera-Amado, C., E. Trujillo-Negrellos, G. Molero, M.P. Reynolds, and M.J. Foulkes (2019). Optimizing dry-matter partitioning for increased spike growth, grain number and harvest index in spring wheat. Field Crops Res. 240: 154-167.

Rosenzweig, C., J. Elliott, D. Deryng, A.C. Ruane, C. Müller, A. Arneth, K.J. Boote, C. Folberth, M. Glotter, N. Khabarov, K. Neumann, F. Piontek, A.M. Pugh-Thomas, E. Schmid, E. Stehfest, H. Yang, and J.W. Jones (2014). Assessing agricultural risks of climate change in the $21^{\text {st }}$ century in a global gridded crop model intercomparison. PNAS 111: 3268-3273.

Shi, H., and M. Shao (2000). Soil and water loss from the Loess Plateau in China. J. Arid Environ. 45: 9-20.

Shimoda, S., T. Hamasaki, T. Hirota, H. Kanno, and Z. Nishio (2015). Sensitivity of wheat yield to temperature changes with regional sunlight characteristics in eastern Hokkaido. Int. J. Climatol. 35: 4176-4185.

Tilman, D., C. Balzer, J. Hill, and B.L. Befort (2011). Global food demand and the sustainable intensification of agriculture. PNAS 108: 20260 20264.

Wang, X.Y., Z. Zhang, X.B. Zhou, P. Liu, and Y.H. Chen (2015). Planting pattern and irrigation effect on farmland microclimate and yield of winter wheat. J. Anim. Plant Sci. 25: 708-715.

Yan, Q., F. Dong, G. Lou, F. Yang, J. Lu, F. Li, J. Zhang, J. Li, and Z. Duan (2018). Alternate row mulching optimizes soil temperature and water conditions and improves wheat yield in dryland farming. J. Integr. Agr. 17: 2558-2569.

Zadoks, J.C., T.T Chang, and C.F. Konzak (1974). A decimal code for the growth stages of cereals. Weed Res. 14: 415-421.

Zhao, C., B. Liu, S. Piao, X. Wang, D.B. Lobell, Y. Huang, M. Huang, Y. Yao, S. Bassu, P.Ciais, J.L. Durand, J. Elliott, F. Ewert, I.A. Janssens, T. Li, E. Lin, Q. Liu, P. Martre, C. Müller, S. Peng, J. Peñuelas, A.C. Ruane, D. Wallach, T. Wang, D. $\mathrm{Wu}, \mathrm{Z}$. Liu, Y. Zhu, Z. Zhu, and S. Asseng (2017). Temperature increase reduces global yields of major crops in four independent estimates. PNAS 114: 9326-9331.

Zhou, X.B., G.Y. Wang, L. Yang, and H.Y. Wu (2020). Double-double row planting mode at deficit irrigation regime increases winter wheat yield and water use efficiency in North China Plain. Agronomy 10(9):1315.

Zhou, X.B., L. Yang, G.Y. Wang, Y.X. Zhao, and H.Y. $\mathrm{Wu}$ (2021). Effect of deficit irrigation scheduling and planting pattern on leaf water status and radiation use efficiency of winter wheat. J. Agron. Crop Sci. 207: https://doi.org/10.1111/jac.12466 